\title{
Interactive M-Learning Design Innovation using Android-Based Adobe Flash at WFH (Work From Home)
}

\author{
Apriade Voutama ${ }^{1 *}$, Iqbal Maulana ${ }^{2}$, Nofriade $^{3}$, Adhi Rizal $^{4}$ \\ ${ }^{1}$ Department of Information System, Faculty of Computer Science, \\ Universitas Singaperbangsa Karawang, Indonesia \\ ${ }^{2,4}$ Department of Informatics Engineering, Faculty of Computer Science, \\ Universitas Singaperbangsa Karawang, Indonesia
}

\begin{abstract}
Purpose: The benefits of technology in education are among the essential factors in the Work From Home (WFH) period. One of these learning media innovations is the design of mobile-based interactive MLearning. Interactive M-Learning is a dynamic learning technology where the learning process contains theory and questions and features animation, game interaction, and sound and video.

Methods: The learning revolution from computers to mobile is an effective way because the mobility and network connections that have been presented on mobile devices make it easier for users to access information as proposed by Mushtaq. Interactive M-Learning applications are designed with UML (Unified Modeling Language) modeling by utilizing several diagrams such as Usecace, Activity, Sequence, Class Diagram to determine the actors involved in the description of the activities that occur in the use of the MLearning system.

Result: The design results are translated into an application using Adobe Flash and then implemented on Android mobile devices. Adobe Flash is software used to create images and animations. The results of MLearning, which have become an application, provide convenience in the distance learning process with a concept.
\end{abstract}

Novelty: It does not provide simple learning but is also attractively designed.

Keywords: WFH, M-Learning, UML, Flash, Android

Received January 2021 / Revised March 2021 / Accepted May 2021

This work is licensed under a Creative Commons Attribution 4.0 International License.

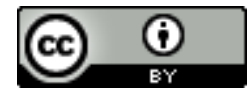

\section{INTRODUCTION}

The impact of the Covid-19 Pandemic has forced all activities to be carried out from home with activity aids, namely technology, and telecommunications media [1]. One thing that is affected is in the field of education. Namely, the learning process must be carried out online, and face-to-face learning activities are not allowed, both from elementary and tertiary institutions [1]. One way to carry out teaching and learning process activities is by utilizing technology [2]. With the development of technology, it can give birth to innovations in designing a new method or container as a tool to facilitate the teaching and learning process that is more modern and easily accepted and provides a feeling of boredom for students so that learning methods can be more lively and more creative [3]. By utilizing existing technology, it can support existing education. A handheld telephone or commonly referred to as a Smartphone, is a technology that cannot be separated from everyday life [4]. Besides being easy to access, cell phones are also easy to use anytime, anywhere and almost all people and students are now using this device as a medium of education [5]. At this time, there are many high-tech mobile telephones circulating in the community. Therefore, smartphones are a very effective learning medium for the current online learning process [5].

Mobile Learning (M-Learning) is learning or exercises carried out using mobile technology devices such as computers, PDAs, cell phones that allow learning to occur anywhere [6]. Meanwhile, Mobile Learning is what learning applies in places and locations that are not specified or learning that applies when students use mobile technology [7]. Many researchers provide a complex definition of Mobile Learning in which

\footnotetext{
* Corresponding Auhtor.

Email addresses: apriade.voutama@staff.unsika.ac.id (Voutama), iqbal.maulana@staff.unsika.ac.id (Maulana), nofriade1994@gmail.com (Nofriade), adhi.rizal@staff.unsika.ac.id (Rizal) DOI:10.15294/sji.v8i1.27880
} 
Mobile Learning can also provide education and practice using PDAs, palmtops, tablet computers, smartphones, and mobile phones [8]. Mobile Learning is learning using mobile devices such as Palms, iPads, PDAs and mobile phones. In addition, Mobile Learning is learning that applies when communication between individuals and other individuals applies wirelessly [9].

Mobile learning architecture can use the infrastructure provided by cellular operators, which in principle is a 3-tier application where there is a front-end layer, application server, and database server [10]. The mobile learning architecture can be seen in the Figure 1.

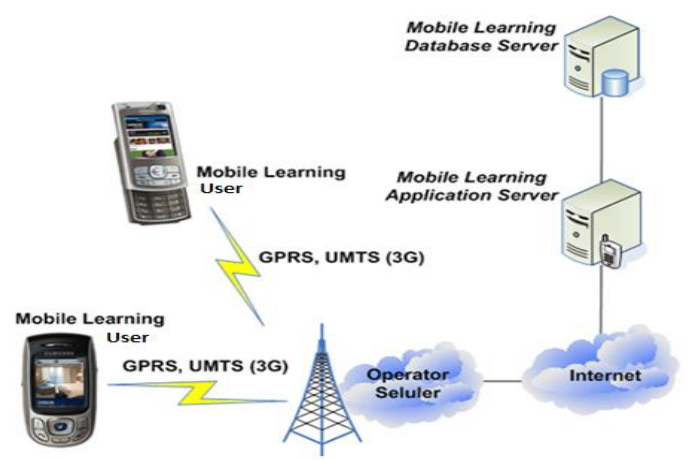

Figure 1. Mobile Learning Architecture

Unified Modeling Language (UML) is a visual language for modeling and communicating about a system using diagrams and supporting texts [11]. UML only serves to perform object-oriented modeling following the demands of today's industry standards [12]. So, the use of UML is not limited because a standardized modeling language is used to analyze and design systems in a graphical way [13]. The development of UML usage depends on the level of abstraction of its use. So, it is not necessarily different views in the use of UML used and what things are visualized [14].

UML version 2.4 was released by the Object Management Group (OMG) in January 2011 and had 14 kinds of diagrams grouped into two categories [15]. The division of categories and kinds of diagrams can be seen in Figure 2 [8].

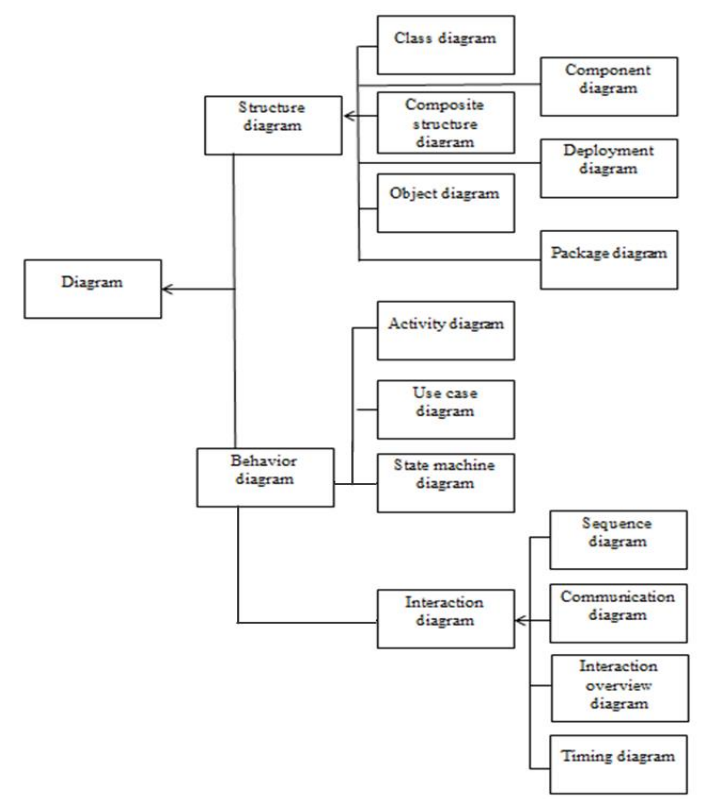

Figure 2. Classification of UML Diagram Types

Adobe Flash is a multimedia software used to facilitate animation, videos, games, and other multimedia applications [16]. Adobe Flash CS6 is software specially designed by Adobe and a professional standard application authoring tool program to create attractive animations for interactive and dynamic website 
development purposes [17]. Flash is also used in making animation, but nowadays, flash is also widely used for other purposes, such as making games, presentations, building learning animations, and even making movies. Animation produced by flash is an animation in the form of a movie file [18]. The resulting movie can be in the form of graphics or text. The graphic referred to here is a vector-based graphic, so that when accessed via the internet, the animation will be displayed faster and look smoother [19]. In addition, Flash also can program graphics that provide reactivity between users in a learning management system [20]. Macromedia Flash has been produced in several versions. The latest version of Macromedia Flash is Macromedia Flash 8 [21]. And now Flash has switched vendors to Adobe. Adobe is a software vendor that buys Flash from a previous vendor, Macromedia. Since then, Macromedia Flash has changed its name to Adobe Flash.

The making of mobile learning uses Adobe Flash CS6 [22]. The start page display for the first time opening Adobe Flash Professional CS6 can be seen in Figure 3.

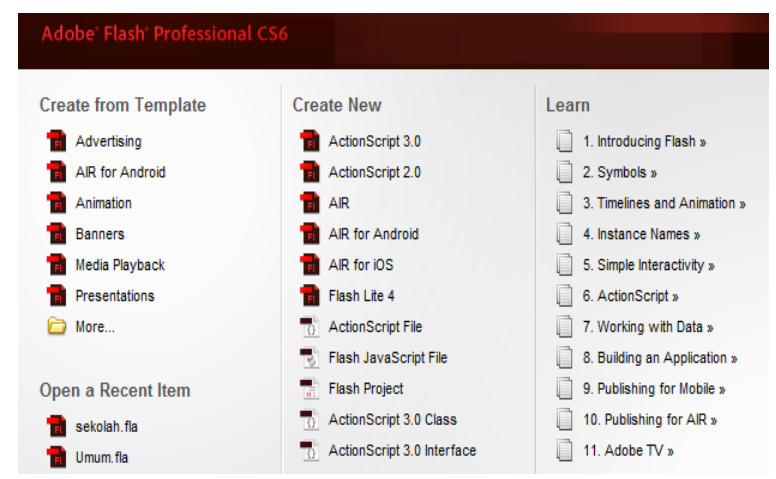

Figure 3. Adobe Flash CS6 Start Page Display

Here are some of the advantages of the Adobe Flash CS6 programming language:

1) Adobe Flash provides support for HTML 5.

2) Adobe Flash provides support for android and Ios with the latest adobe flash player.

3) Quick export of symbols and animation sequences resulting in sheet scripts for enhanced gaming experience, workflow, and performance.

4) Adobe Flash provides support for making applications that look attractive with 2-dimensional animation (moving images).

5) Adobe Flash can be used on a vast network.

The purpose of this research is to create a mobile-based learning application using Adobe Flash CS6 software by exploring the Flash facility so that it not only produces products in the form of images and animations but can also produce interactive applications for learning media.

\section{METHODS}

This M-Learning design method uses the SDLC (Software Development Life Cycle) discipline with the Waterfall method. The following is the research framework seen in Figure 4.

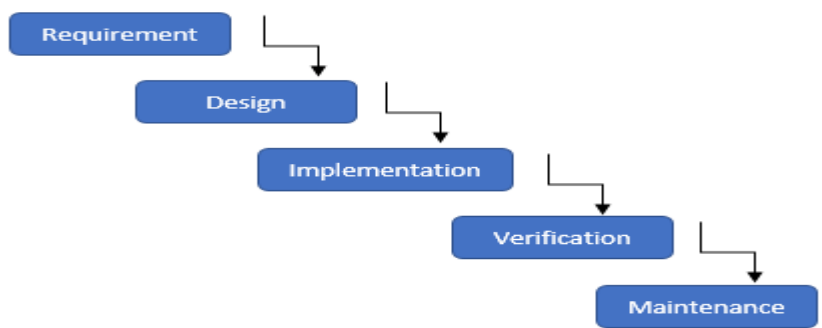

1) Requirement

Figure 4. Research Framework (Waterfall)

System analysis and software requirements and collecting information data related to the design of new applications in the form of observations, interviews, studies of literature needs. 
2) Design

The modeling process is carried out when the needs analysis process is complete. It is carried out by modeling the scheme using several UML models. The results of this design are an initial description of the M-Learning application that will be built before being translated into a programming language.

3) Implementation The process of translating the design results in a programming language so as to produce an M-Learning application. At this stage, the concoction process is in the form of an application.

4) Verification

This stage is the stage where testing of applications that have been made is carried out in order to look for debugging or application defects.

5) Maintenance

At this stage, software maintenance and maintenance are carried out when the M-Learning software has been used.

Some UML diagrams are used in the design process of M-Learning applications to make it easier for Developers to code into an application.

1) Usecase Diagram

This diagram is an initial diagram used as a system analysis tool. The initial analysis determines what actors are involved with the system and what activities can be carried out by the actors.

2) Activity Diagram

This diagram is used to create a flow of system activities based on predetermined actors.

3) Sequence Diagram

This diagram is a breakdown of the activity diagram used to clarify the flow of all activities of one actor.

4) Deployment Diagram

It has entered the design stage, where this diagram is used to provide an overview of what software and hardware are used.

\section{RESULT AND DISCUSSION}

The results and discussion of M-Learning are described in use-case, activity, sequence, deployment, interface, and system testing.

\section{Usecase Diagram}

At the analysis stage, a use-case diagram in Figure 5 is needed as a tool. Two actors will be used in the system, namely the user and admin, and depicted the functions in the mobile learning application shown in Table 1.

Table 1. Definition of Actors

\begin{tabular}{cll}
\hline Num & Actors & \multicolumn{1}{c}{ Description } \\
\hline 1 & User & $\begin{array}{l}\text { Users are application users who can access information about } \\
\text { application update info, view application developer info, view } \\
\text { competencies, view material, users can also practice } \\
\end{array}$ \\
& & $\begin{array}{l}\text { understanding of the material with the evaluation menu, users } \\
\text { can also listen to sounds, and send suggestions with the } \\
\text { suggestion menu, }\end{array}$ \\
& Admin & $\begin{array}{l}\text { Admin is an application manager that can update the system in } \\
\text { both user applications, learning materials using web-based } \\
\text { applications. }\end{array}$ \\
\hline
\end{tabular}




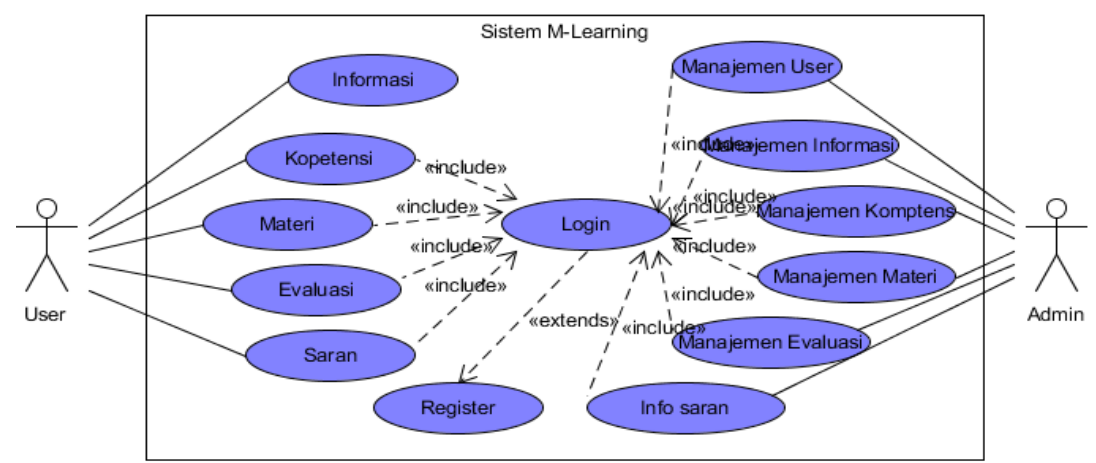

Figure 5. Usecase Diagram

\section{Activity Diagram}

Activity diagrams of the analysis stages to describe the activities that can be carried out by actors in this M-Learning application. In Figure 6, we can see the user's activities, namely accessing the main menu, info, competencies, materials, evaluation, donations, and suggestions on the application.

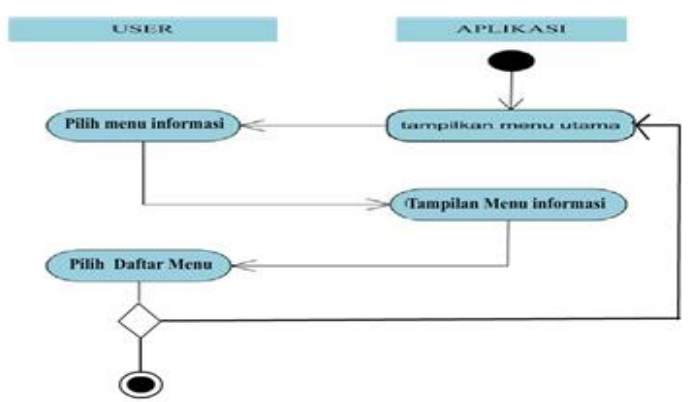

Figure 6. User Page Activity Diagram

The activity diagram of the material menu can be seen in Figure 7.

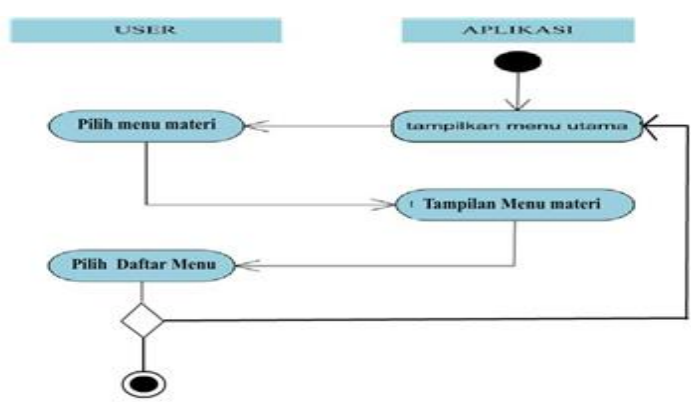

Figure 7. Activity Diagram See Material

The activity diagram for the exercise menu can be seen in Figure 8 .

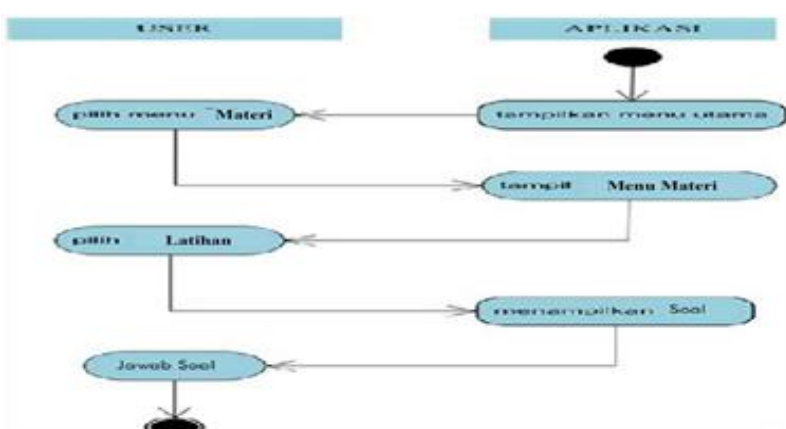

Figure 8. Activity Diagram of Exercises 


\section{Sequence Diagram}

Sequence diagrams are descriptions of object interactions arranged in time sequence. The following diagram is specifically associated with use-case. This sequence diagram shows step by step what must happen to produce a use case diagram. Figure 9 is a sequence diagram image for designing M-Learning applications.

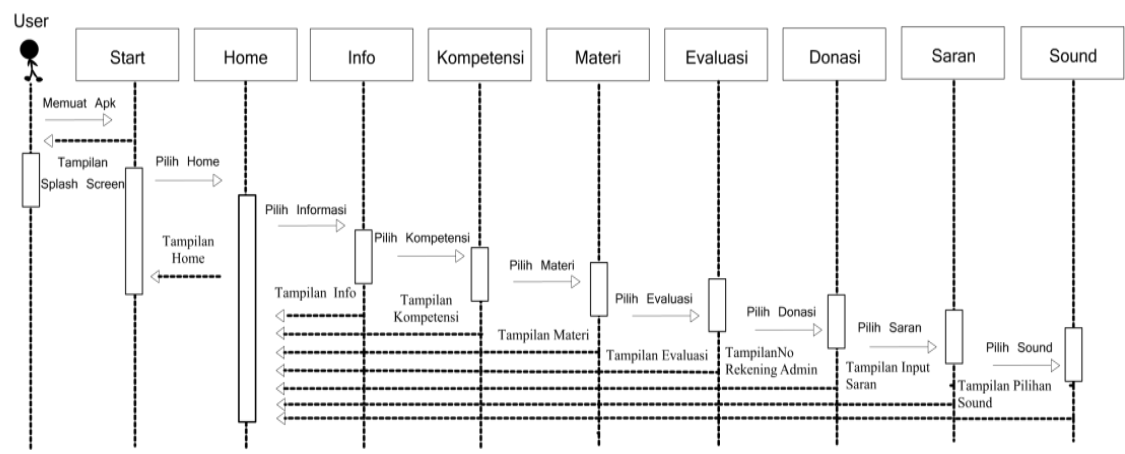

Figure 9. Main Page Sequence Diagram

The sequence diagram of the material menu can be seen in Figure 10.

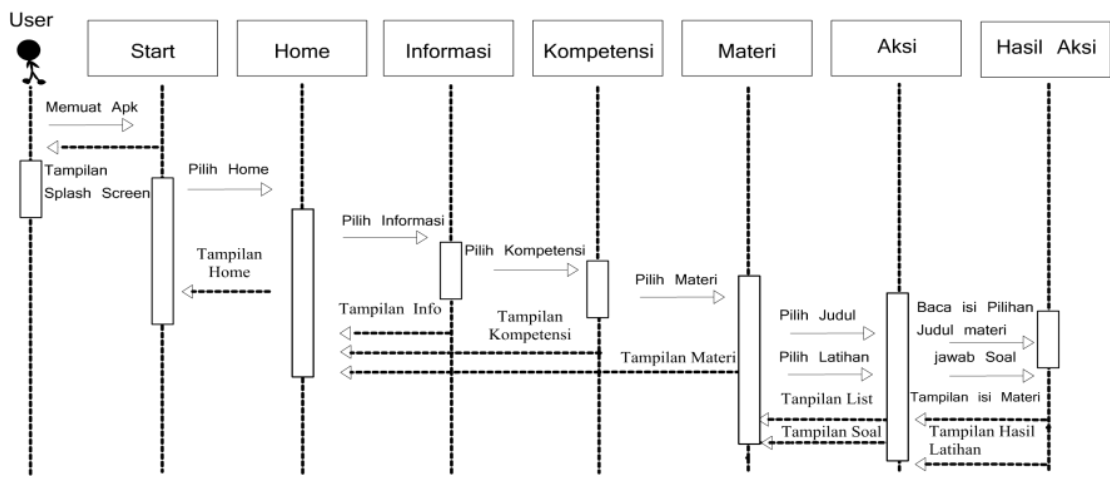

Figure 10. Sequence Diagram of the Material

The image of the evaluation menu sequence diagram can be seen in Figure 11.

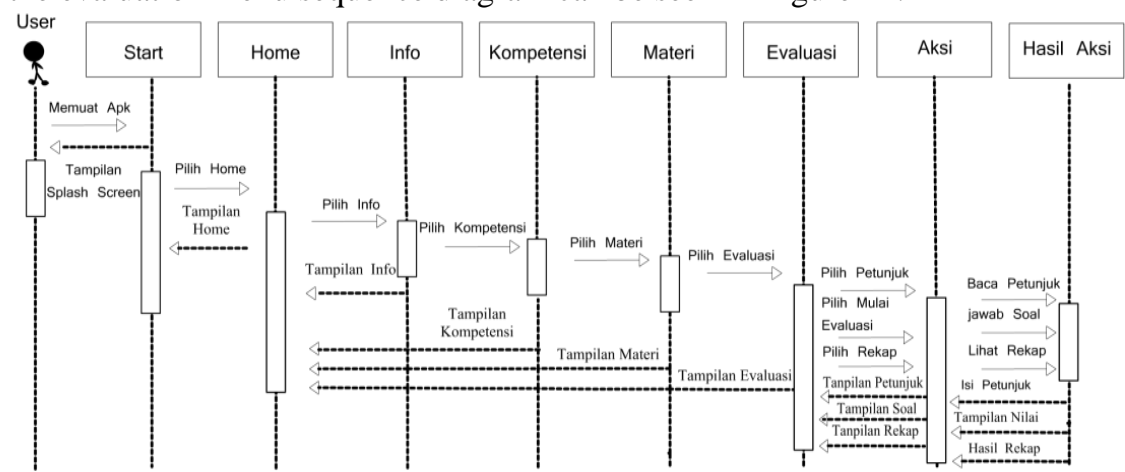

Figure 11. Sequence Diagram of Evaluation

\section{Deployment Diagram}

This stage has entered into the design where this diagram shows the configuration of the components in the application execution process. This M-Learning application was built to be accessible via a mobile application specially made for installation on an Android-based mobile device, this mobile learning application has an application in the form of a web, and the application on the user will automatically process the application on the server. The deployment diagram is shown in Figure 12. 


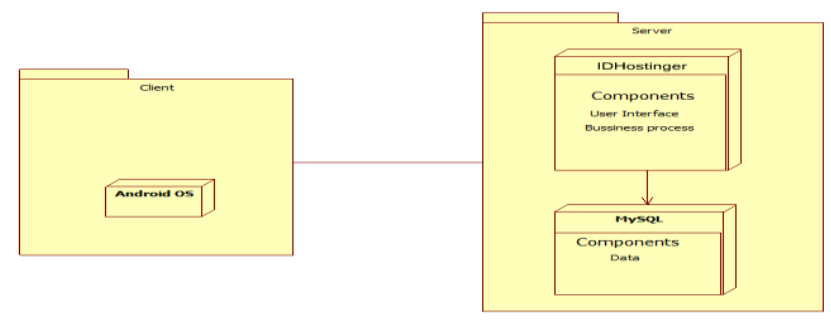

Figure 12. Deployment Diagram

\section{Interface Design}

The interface is a concoction stage for an overview of the appearance of the application to be made. Material options will appear when the user selects the material menu. If the material is selected, the application will display a new page that contains a list of materials. The user can select the list of material about learning information technology in various fields by selecting the button to the new page in the form in Figure 13.

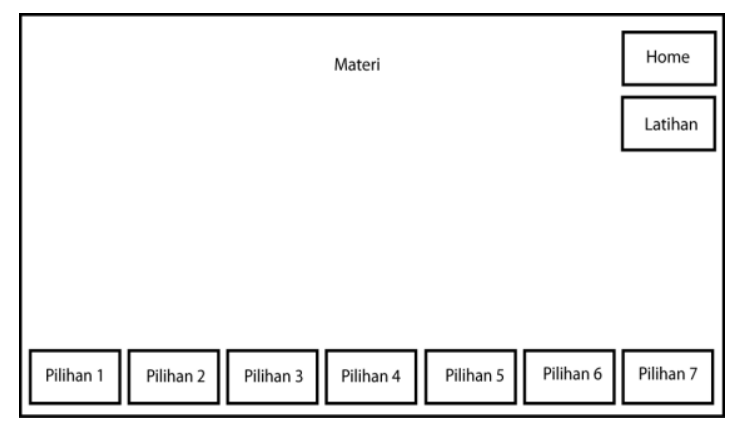

Figure 13. Interface Material

The application material menu also provides a training menu to train users understanding in understanding the material. When the user selects the exercise menu, the application will display a new page in practice questions like Figure 14.

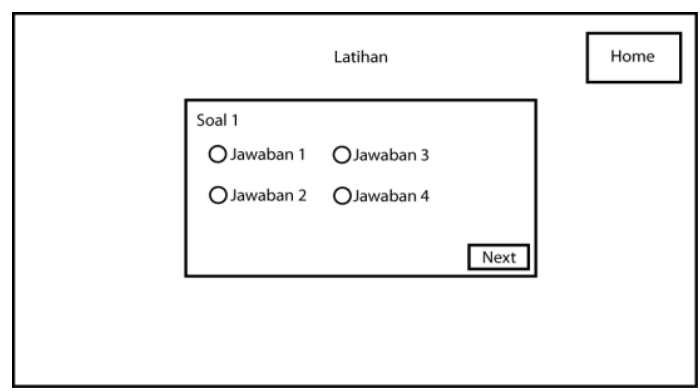

Figure 14. Training Interface

\section{Testing Systems}

Mobile Learning is built using Adobe Flash CS6. After the application design and installation is complete, the application launcher icon will be visible on the menu system of the mobile device. The main menu displays menus selected by the user, such as information, competence, evaluation, suggestions, and sound like Figure 15. 


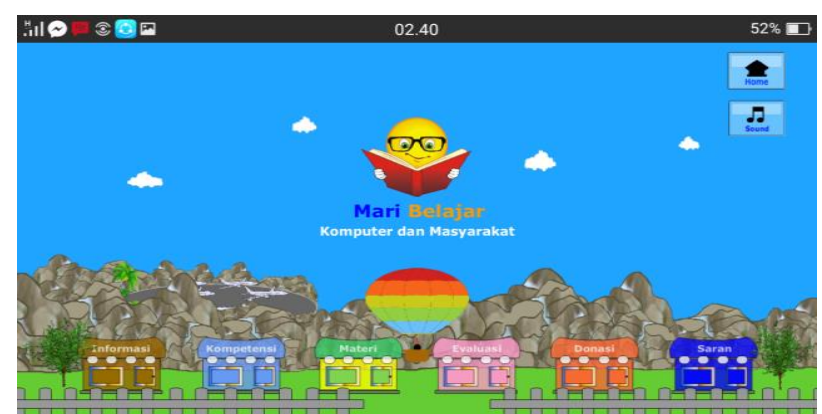

Figure 15. Main Menu Display

Users can read the material by selecting the material menu. On this material menu page, there are various buildings as buttons to view the material's content like Figure 16.

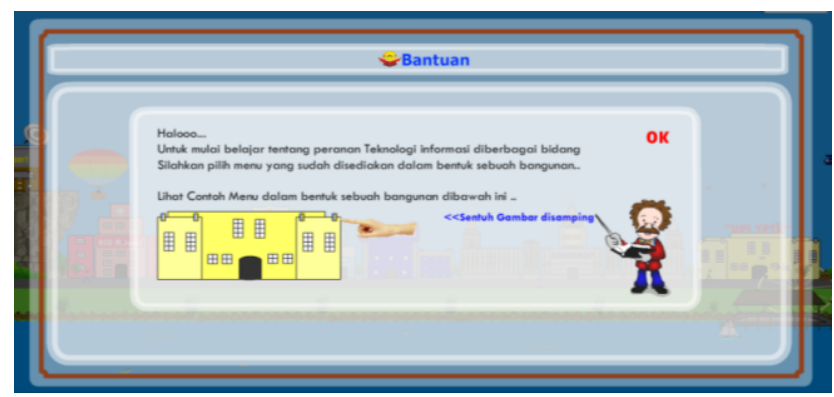

Figure 16. Material Display

When the user selects the exercise menu, the application will display a new page in practice questions. The system in practice questions is that the user will not continue to the next question before the user correctly answers the questions. The assessment of the practice questions is in the form of a picture of the correct or wrong answer chosen by the user, like Figure 17.

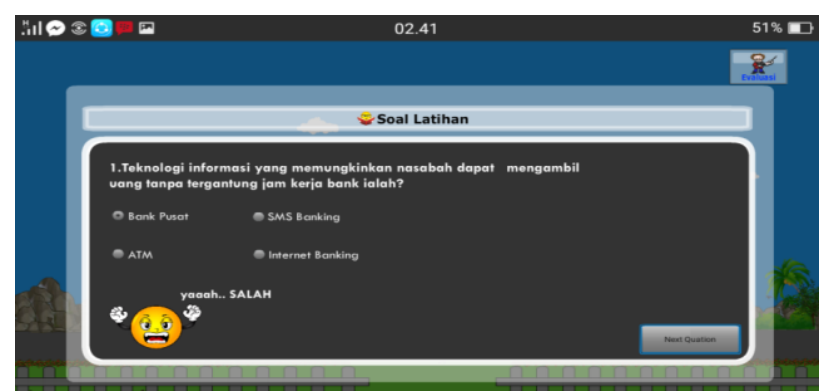

Figure 17. Exercise View

The application evaluation menu will display a new page, namely the exam form page. The following image displays the test form page for the user before conducting the evaluation test like Figure 18.

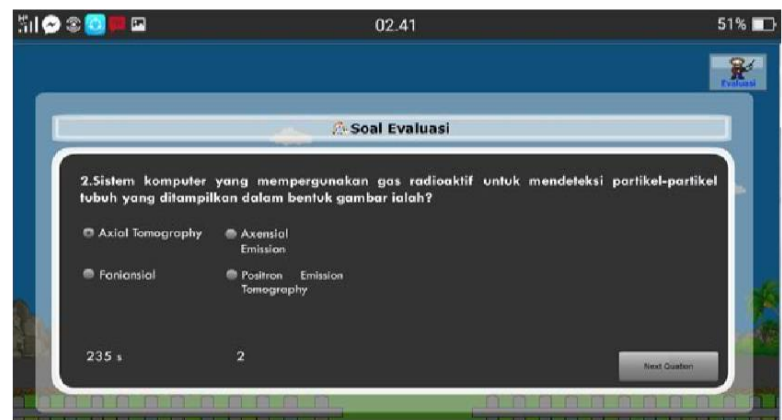

Figure 18. Evaluation Display 


\section{Test Results}

The test result data from the application that has been developed is done through a questionnaire to 30 respondents, namely students of class VII who were randomly selected. The questionnaire is shown in Table 2.

Table 2. Questionnaire

\begin{tabular}{lll}
\hline No & \multicolumn{1}{c}{ Questions } & $\begin{array}{c}\text { Rating } \\
\text { Excellent }\end{array}$ \\
\hline 1 & & What is your assessment of this Android-based M-Learning? \\
2 & What is your assessment about M-Learning that can interact with you? \\
3 & What is your assessment of the visual appearance of M-Learning? \\
4 & What is your assessment of the delivery of unique material accompanied by animation \\
& and sound? \\
5 & What is your assessment of the practice questions that are displayed uniquely and \\
6 & interactively, like playing games? \\
7 & What is your assessment of the ease of using this M-Learning application? \\
8 & How do you rate the speed or inadequacy of the app interacting with you? \\
9 & How do you evaluate the appearance of M-Learning which is still two-dimensional? \\
10 & How do you rate all the features of this application?
\end{tabular}

The assessment is divided into three levels, namely Excellent, Bad, Good. Each respondent chooses the level of their satisfaction with the application that has been developed, along with the results obtained. The Application satisfaction result is shown in Table 3.

\begin{tabular}{cccc}
\multicolumn{4}{c}{ Table 3. Application Satisfaction Results } \\
\hline No & Bad & Good & Excellent \\
\hline 1 & 0 & 2 & 28 \\
2 & 0 & 1 & 29 \\
3 & 0 & 3 & 27 \\
4 & 0 & 0 & 30 \\
5 & 0 & 2 & 28 \\
6 & 1 & 4 & 25 \\
7 & 1 & 3 & 26 \\
8 & 3 & 8 & 19 \\
9 & 0 & 6 & 24 \\
10 & 0 & 0 & 30 \\
\hline
\end{tabular}

Analysis of the results of application implementation based on respondent satisfaction, the satisfaction level of Excellent $89 \%$, Good 10\%, and Bad 2\% was obtained.

\section{CONCLUSION}

The conclusion that can be obtained from applying the M-Learning application is a tool for system analysis and design using UML modeling by making use-case, activity, sequence, and deployment diagram design drawings. As an illustration of the system, an interface design is made to facilitate the design process using Flash CS6 software. The M-Learning application built using Flash CS6 has been successfully implemented on Android-based mobile devices. M-Learning is developed using 2-dimensional animation (moving image) visual, sound and animation to increase learning attractiveness. The level of excellent respondent satisfaction with the M-Learning application reaches $89 \%$ with an easy access mode only through student devices. The limit and time do not hinder that users can study anywhere and anytime using their mobile devices.

\section{REFERENCES}

[1] A.W. Putri., \& Irwansyah, "Communication Patterns and Media Technology Role in Organization and Society During Pandemic,” J. Soc. Media., vol. 4, no. 2, pp. 228-26, 2020.

[2] A. Purwanto, M. Asbari, M. Fahlevi, A. Mufid, "Impact of Work From Home (WFH) on Indonesian Teachers Performance During the Covid-19 Pandemic: An Exploratory Study," Int. J. Adv. Sci. Technol., vol. 29, no. 5, pp. 6235-6244, 2020.

[3] T Hongthong., \& P. Temdee "Personalized Mobile Learning for Digital Literacy Enhancement of Thai Youth,” Int. Workshop Adv. Image Technol. (IWAIT)., Chiang Mai: IEEE, 2018. 
[4] A. Krasulia, \& K. Saks "Students' perceptions towards mobile learning in an English as a foreign language class," Int. Conf. Adv. Learn. Technol. (ICALT)., pp. 238-240, 2020.

[5] F. Ozdamli, N. "Cavus Basic elements and characteristics of mobile learning," Procedia - Soc. Behav. Sci., vol. 28, pp. 937 - 942, 2011.

[6] H. Zhang, M. Wang, \& A. Marquez "A Case Study of Collaborative Mobile Learning in Large-size Classes,” Int. Conf. Eng. Technol. Educ. (TALE)., Yogyakarta: IEEE, 2019.

[7] M. Kearney, S. Schuck, K. Burden, P. Aubusson, "Viewing mobile learning from a pedagogical perspective" Res. Learn. Technol., vol. 20, pp. 1-17, 2012.

[8] T. Listyorini, \& A. Widodo, "Perancangan Mobile Learning Mata Kuliah Sistem Operasi Berbasis Android,” J. Simetris., vol. 3, no. 1, pp. 25-30, 2013.

[9] I.A. Astuti, R.A. Sumarni, D.L. Saraswati, "Pengembangan Media Pembelajaran Fisika Mobile Learning berbasis Android," J. Penelit. Pengemb. Pendidik. Fis., vol. 3, no. 1, pp. 57-62, 2017.

[10] M. Ibrahim, \& Ishartiwi "Pengembangan Media Pembelajaran Mobile Learning Berbasis Android Mata Pelajaran IPA untuk Siswa SMP,” J. Refleksi Edukatika., vol. 8, no. 1, pp. 80-88, 2017.

[11] Rosa dan M. Shalahuddin "Rekayasa Perangkat Lunak: Terstruktur dan Berorientasi Objek," Bandung: Informatika, 2013.

[12] S.A. Shah, S. S. Bukhari, M. Humayun, Jhanjhi, S.F. Abbas, "Test Case Generation using Unified Modeling Language,” Int. Conf. Comput. Inf. Sci. (ICCIS)., Sakaka: IEEE, 2019.

[13] L. Jin, \& J. Liang "Modeling of Vehicle Administrative Management System Based on Unified Modeling Language," Inf. Technol. Mechatron. Eng. Conf. (ITOEC)., Chongqing: IEEE, 2017.

[14] J. Liang \& L. Jin, "Multi-perspective modeling of computer sales system Based on Unified Modeling Language," Inf. Technol. Mechatron. Eng. Conf. (ITOEC)., Chongqing: IEEE. (2020).

[15] J. Tomyim, \& A. Pohthong, "Requirements Change Management Based on Object-Oriented Software Engineering with Unified Modeling Language,” Int. Conf. Softw. Eng. Serv. Sci. (ICSESS)., Beinjing: IEEE. 2016.

[16] Q. Min, Z. Wang, M. Wu, “An Evaluation of Adobe Flash for Remote Access Medical Imaging Applications," Int. Congr. Image Signal Process. BioMed. Eng. Inform. (CISP-BMEI)., Datong: IEEE, 2016.

[17] Wahana Komputer, “Mudah membuat game android berbasis adobe air,” Yogyakarta: Andi, 2014.

[18] N. Hannah, H Qodim, R.W. Sururie, R. Rahim, "Flash Multimedia Application: An E Learning Arabic Language for Mastering Fluency in Reading the Qur'an," Int. Conf. Cyber IT Serv. Manag. (CITSM)., Jakarta: IEEE, 2019.

[19] L. Sukariasih, Erniwati, A. Salim, “The Development of Interactive Multimedia on Science Learning Based Adobe Flash CS6," Int. J. Educ. Vocat. Stud., vol. 1, no. 4, pp. 322-329, 2019.

[20] O. Yilmaz, \& K. Tuncalp, “A Mixed Learning Approach in Mechatronics Education,” IEEE Trans. Educ., vol. 54, no. 2, pp. 294-301, 2011.

[21] D. Ampera, "Adobe Flash CS6-Based Interactive Multimedia Development for Clothing Pattern Making,” Int. Conf. Technol. Vocat. Teach., pp. 314-318. Atlantic Press, 2017.

[22] M. I Hanafri., A. Budiman, N.A. Akbar, "Game Edukasi Tebak Gambar Bahasa Jawa Menggunakan Adobe Flash CS6 Berbasis Android,” J. Sisfotek Glob., vol. 5, no. 2, pp. 50-53, 2015. 